\title{
The Incidence of Precancerous and Cancerous Skin Lesions: A Retrospective Multicenter Study
}

\author{
Berna Aksoy, ${ }^{1,2}$ Aslı Tatlıparmak, ${ }^{1,3}$ Funda Tamer, ${ }^{4}$ Can Ergin, ${ }^{5}$ Erol Koç,5
}

'Department of Dermatology, Bahçeşehir University Faculty of Medicine, İstanbul, Turkey ${ }^{2}$ Department of Dermatology, VM Medicalpark Hospital, Kocaeli, Turkey ${ }^{3}$ Department of Dermatology, Fatih Medicalpark Hospital, İstanbul, Turkey ${ }^{4}$ Department of Dermatology, Ufuk University Faculty of Medicine, Ankara, Turkey

${ }^{5}$ Department of Dermatology, Medicalpark Hospital, Ankara, Turkey

Submitted: 31.10.2017 Accepted: 30.11 .2017

Correspondence: Berna Aksoy, VM Medicalpark Hastanesi, Ovacık Mah., D-100 Karayolu Üstü, No: 36,

Başiskele, 41100 Kocaeli, Turkey

E-mail:bmaksoy@mynet.com

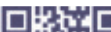

NTrix

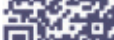

Keywords: Actinic keratosis;

basal cell carcinoma; cancer; incidence; precancerous; squamous cell carcinoma.

\begin{abstract}
Objective: As the frequency of skin cancers continues to increase, the aim of this study was to determine the incidence of precancerous and cancerous skin lesions diagnosed and treated during 2016 at the dermatology outpatient clinics of 3 private hospitals in 3 cities in Turkey.
\end{abstract}

Methods: All of the patients who presented at 3 outpatient clinics located in the Marmara and Anatolian regions of Turkey in 2016 were retrospectively evaluated. Patients with precancerous and cancerous skin lesions were identified via the relevant International Classification of Diseases code, and sociodemographic and clinical features were obtained from their medical records.

Results: Among the 2I,085 patients who presented at the 3 study centers, there were 81 cases of precancerous or cancerous skin lesions. The annual combined incidence of precancerous and cancerous skin lesions was $0.38 \%$. The incidence of precancerous lesions $(n=58)$ was $0.27 \%$, while it was $0.11 \%(n=23)$ for cancerous lesions.

Conclusion: The prevalence of precancerous and cancerous skin lesions is increasing worldwide. The results of this study were consistent with the findings previously detected in this country and worldwide. This study included patients from only 2 regions of Turkey, but the findings could be used as a reference for dermatology outpatient clinics located in second level healthcare facilities.

\section{INTRODUCTION}

Although benign, skin lesions with a $>10 \%$ chance of becoming cancerous over time are referred to precancerous lesions. ${ }^{[l]}$ Precancerous skin lesions include actinic keratosis (AK), Bowen's disease, Queyrat erythroplasia, Bowenoid papulosis, and parapsoriasis en plaques. The frequency of skin cancers is increasing worldwide. Cancerous skin lesions include basal cell carcinoma (BCC) and squamous cell carcinoma (SCC) (the 2 most common), malignant melanoma (MM), mycosis fungoides (MF), Kaposi's sarcoma, and other rare skin appendageal tumors. The aim of the present study was to determine the incidence of precancerous and cancerous skin lesions diagnosed and treated in 2016 at the dermatology outpatient clinics of 3 private secondary healthcare centers in 3 cities in Turkey.

\section{MATERIAL AND METHODS}

This retrospective multicenter study examined the records of all patients who presented at the dermatology outpatient clinic at Ankara Medicalpark Hospital, Ankara, Turkey; Kocaeli VM Medicalpark Hospital, Kocaeli, Turkey; and Istanbul Fatih Medicalpark Hospital, Istanbul, Turkey (all 
secondary private healthcare institutions) during 2016. The number of patients, the male to female ratio, and mean age were calculated. The International Classification of Diseases codes were used to identify patients clinically and/or histopathologically diagnosed with precancerous and cancerous skin lesions, and then the patients' demographic and clinical details were obtained from their medical records. The study protocol was approved by the Bahçeşehir University Ethics Committee (BAU KAEK 2017-04/0I), and the study was conducted in accordance with the Declaration of Helsinki.

Descriptive statistics are shown as mean $\pm \mathrm{SD}$, median, range, frequency, and percentage. The normality of the distribution of the data was determined via the KolmogorovSmirnov test. The Mann-Whitney $U$ test was used to analyze independent quantitative data. Independent qualitative data were analyzed using a chi-square test and Fischer's test was used when the chi-square test conditions were not met. Data analysis was performed using IBM SPSS Statistics for Windows, Version 22.0 (IBM Corp., Armonk, NY, USA). The level of statistical significance was set at $p<0.05$.

\section{RESULTS}

A total of 21,085 patients presented at the 3 dermatology outpatient clinics in 2016. Patient characteristics are summarized in Table I. Among the patients, there were $8 \mathrm{I}$ cases of precancerous and cancerous lesions, for an annual incidence of $0.38 \%$. The annual incidence of precancerous lesions $(n=58)$ was $0.27 \%$, versus $0.11 \%(n=23)$ for cancerous lesions (Table 2). Precancerous lesions included AK, Bowen's disease, Bowenoid papulosis, and parapsoriasis, and cancerous lesions diagnosed included BCC, SCC, MM, MF, Kaposi's sarcoma, and skin metastasis of distant organ cancers (Table 3).

Table I. Patient characteristics

\begin{tabular}{|c|c|c|c|c|c|c|c|c|c|}
\hline \multirow[t]{2}{*}{ Hospital } & \multicolumn{3}{|c|}{ Female } & \multicolumn{3}{|c|}{ Male } & \multicolumn{3}{|c|}{ Total } \\
\hline & $\mathbf{n}$ & $\%$ & Mean age (years) & $\mathbf{n}$ & $\%$ & Mean age (years) & $\mathbf{n}$ & $\%$ & Mean age (years) \\
\hline Kocaeli & 3112 & 61.9 & 31.8 & 1912 & 38.1 & 32.2 & 5024 & 100 & 32 \\
\hline Istanbul & 3150 & 56.8 & 32.6 & 2397 & 43.2 & 41 & 5547 & 100 & 36.8 \\
\hline Ankara & 6271 & 59.6 & 37.3 & 4243 & 40.4 & 36.6 & 10.514 & 100 & 36 \\
\hline Total & 12.533 & 59.4 & 34.8 & 8552 & 40.6 & 36.9 & 21.085 & 100 & 35.3 \\
\hline
\end{tabular}

Table 2. The I-year incidence of precancerous and cancerous skin lesions

\begin{tabular}{|c|c|c|c|c|c|c|c|}
\hline & \multicolumn{2}{|c|}{ Precancerous } & \multicolumn{2}{|c|}{ Cancerous } & \multicolumn{2}{|c|}{$\begin{array}{l}\text { Total dermato-oncological } \\
\text { patient presentations }\end{array}$} & \multirow{2}{*}{$\frac{\text { Total patient presentations }}{n}$} \\
\hline & $\mathbf{n}$ & $\%$ & $\mathbf{n}$ & $\%$ & $\mathbf{n}$ & $\%$ & \\
\hline Kocaeli & 20 & 0.40 & 12 & 0.24 & 32 & 0.64 & 5024 \\
\hline Istanbul & 10 & 0.18 & 4 & 0.07 & 14 & 0.25 & 5547 \\
\hline Ankara & 28 & 0.26 & 7 & 0.07 & 35 & 0.33 & 10.514 \\
\hline Total & 58 & 0.27 & 23 & 0.11 & 81 & 0.38 & 21.085 \\
\hline
\end{tabular}

Table 3. The distribution of patients with precancerous and cancerous skin lesions

\begin{tabular}{lcclcc}
\hline Precancerous & \multicolumn{5}{l}{ Cancerous } \\
\hline Diagnosis & $\mathrm{n}$ & $\%$ & Diagnosis & $\mathrm{n}$ & $\%$ \\
Actinic keratosis & 52 & 64.2 & Basal cell carcinoma & 6 & 7.4 \\
Bowen's disease/Bowenoid papulosis & 2 & 2.5 & Squamous cell carcinoma & 6 & 7.4 \\
Parapsoriasis & 4 & 4.9 & Malignant melanoma & 3 & 3.7 \\
& & & Mycosis fungoides & 7.4 \\
& & & Kaposi sarcoma & 1 & 1.2 \\
Total & & Skin metastasis & & 1.2 \\
& 58 & 71.6 & & & 28.4 \\
\hline
\end{tabular}


Table 4. Characteristics of the patients with precancerous and cancerous skin lesions

\begin{tabular}{|c|c|c|c|c|c|c|c|c|c|c|}
\hline & \multicolumn{3}{|c|}{ Precancerous } & \multicolumn{3}{|c|}{ Cancerous } & \multirow[t]{2}{*}{$\mathbf{p}$} & \multicolumn{3}{|c|}{ Total } \\
\hline & $\mathbf{n}$ & $\%$ & Mean $\pm S D$ & $\mathbf{n}$ & $\%$ & Mean $\pm S D$ & & $\mathbf{n}$ & $\%$ & Mean \pm SD \\
\hline Age (years) & & & $65.4 \pm 17.4$ & & & $59.4 \pm 16.0$ & 0.094 & & & $63.7 \pm 17.1$ \\
\hline \multicolumn{11}{|l|}{ Gender } \\
\hline Female & 31 & 53.4 & & 12 & 52.2 & & 0.917 & 43 & 53.1 & \\
\hline Male & 27 & 46.6 & & II & 47.8 & & & 38 & 46.9 & \\
\hline Lesion duration (months) & & & $20.6 \pm 21.3$ & & & $21.3 \pm 28.0$ & 0.494 & & & $20.8 \pm 23.3$ \\
\hline \multicolumn{11}{|l|}{ Localization } \\
\hline Head \& neck & 51 & 87.9 & & 12 & 52.2 & & 0.000 & 63 & 77.8 & \\
\hline Trunk & 2 & 3.4 & & 6 & 26.1 & & 0.002 & 8 & 9.9 & \\
\hline Extremity & 7 & 12.1 & & 8 & 34.8 & & 0.018 & 15 & 18.5 & \\
\hline \multicolumn{11}{|l|}{ Lesion count } \\
\hline 1 & 15 & 25.9 & & 13 & 56.5 & & 0.018 & 28 & 34.6 & \\
\hline $2-5$ & 15 & 25.9 & & 3 & 13.0 & & & 18 & 22.2 & \\
\hline $6-10$ & 10 & 17.2 & & 3 & 13.0 & & & 13 & 16.0 & \\
\hline$>10$ & 18 & 31.0 & & 4 & 17.4 & & & 22 & 27.2 & \\
\hline Biopsy diagnosis & 5 & 8.6 & & 16 & 69.6 & & 0.000 & 21 & 25.9 & \\
\hline \multicolumn{11}{|l|}{ Applied therapy } \\
\hline Topical & 22 & 37.9 & & 4 & 17.4 & & 0.268 & 26 & 32.1 & \\
\hline Cryosurgery/electrosurgery & 32 & 55.2 & & I & 4.3 & & 0.001 & 33 & 40.7 & \\
\hline Surgery & I & 1.7 & & 7 & 30.4 & & 0.001 & 8 & 9.9 & \\
\hline Other & I & 1.7 & & 4 & 17.4 & & 0.021 & 5 & 6.2 & \\
\hline
\end{tabular}

SD: Standard deviation.

Patient age and gender, hospital distribution, the comorbid disease rate, and lesion duration did not differ significantly between the patients with precancerous and cancerous lesions $(p>0.05)$. Head and neck localization, and the incidence of $\geq 2$ lesions were significantly higher $(p<0.05)$ in the patients with precancerous lesions than in those with cancerous lesions. Significantly more patients with cancerous lesions underwent biopsy, surgical treatment, and other treatments (radiotherapy, chemotherapy, and phototherapy), compared with those with precancerous lesions $(p<0.05)$. The cryosurgery/electrosurgery rate was significantly higher in the patients with precancerous lesions than in those with cancerous lesions $(p<0.05)$. The rate of topical treatment (topical corticosteroids, 5-fluorouracil $5 \%$ cream and diclofenac sodium $3 \%$ cream) did not differ significantly $(p>0.05)$ between the patients with precancerous and cancerous lesions (Table 4).

\section{DISCUSSION}

The prevalence of precancerous and cancerous skin lesions is increasing worldwide. ${ }^{[2]}$ Turkey is bound by 3 seas and is located between the temperate and subtropical cli- mate zones. As such, precancerous and cancerous skin lesions, especially due to the effects of sunlight, are common in Turkey. The incidence of cancer among all pathology specimens obtained in Mersin, Turkey between 1989 and 1999 was $7.71 \%$, of which the most common was skin cancer $(22.38 \%$ of all cancer cases and $1.73 \%$ of all pathology specimens). ${ }^{[3]}$ A study on the I-year incidence of cancer in Hatay, Turkey reported that the most common cancer was skin cancer (27.7\%). ${ }^{[4]}$ Two other retrospective studies conducted in Turkey included all dermatology patients aged $>65$ years, reporting that the frequency of precancerous and cancerous skin lesions was $5.2 \%$ to $9.4 \%,{ }^{[5,6]}$ and that it increased with patient age (4.6\%-12.5\%). ${ }^{[5]}$ Additionally, it was reported that between 1999 and 2003 the frequency of precancerous and cancerous skin lesions in Turkey increased almost 1.5 -fold (4.0\%-6.4\%). ${ }^{\left[{ }^{[}\right]}$

One Turkish study observed that skin tumors are the most common skin finding in the population aged $>65$ years in Ankara, with a rate of $81.5 \%$, including benign, precancerous, and cancerous tumors, and that among the precancerous skin tumors, $19 \%$ were $A K{ }^{[7]}$ A retrospective study of geriatric patients who presented at a dermatology outpatient clinic in Yozgat, Turkey reported that the frequency of 
AK was $3.8 \%{ }^{\left[{ }^{[6]}\right.}$ A Korean study found that the prevalence of precancerous skin lesions was $0.16 \%$ (7I.2\% of all cases were AK). ${ }^{[2]}$ Another Korean study observed that the annual incidence of precancerous skin lesions was $1.82 \%{ }^{[8]}$ The frequency of AK in the northern hemisphere is $11 \%$ to $25 \%$ in the population aged $>40$ years. ${ }^{[9]}$ In a British study, it was reported that the incidence of AK was $3 \%$ to $6 \%$ in males aged $40-49$ years and $20 \%$ in males aged $>60$ years. ${ }^{[9]}$ Dutch researchers reported that the prevalence of AK in males aged $>45$ years was $49 \%$, while it was $28 \%$ in females similarly aged. ${ }^{[10]}$ In the present study, the mean age of all of the patients was 35.3 years, whereas the mean age of the patients with precancerous skin lesions was 65.4 years. In addition, among the present study's patient population, the annual incidence of presentation due to AK was $0.25 \%$, versus $0.28 \%$ due to precancerous skin lesions.

Korean research found an incidence of cancerous skin lesions of $0.3 \%{ }^{[2]}$ The retrospective study of geriatric patients who presented at a dermatology outpatient clinic in Yozgat reported that the incidence of cancerous skin lesions was $1.36 \% .{ }^{[6]}$ A retrospective study from China that included 19 years of data reported that a biopsy-based diagnosis of precancerous and cancerous lesions was prevalent among lesions of the head and neck, trunk, and extremities, and that mean age at diagnosis was 62.27 years. ["I] In that Chinese study, BCC was the most commonly diagnosed cancer, followed by AK, SCC in situ, SCC, MF, and MM. A Turkish study on AK biopsy specimens observed that $13 \%$ of AK lesions were harboring SCC and $19 \%$ were harboring BCC. ${ }^{[2]}$ Turkish research on the frequency of skin findings in individuals aged $>65$ years reported that $1 \%$ of cancers were BCC. ${ }^{[7]}$ The study of geriatric dermatology outpatient patients in Yozgat found that the frequency of BCC was $0.81 \%$, versus $0.27 \%$ for SCC. ${ }^{[6]}$ The annual incidence of SCC was reported to be $0.03 \%$ in the general French population. ${ }^{[9]}$ In the study of pathology specimens in Mersin, it was determined that among all skin cancers, the most common was BCC $(74.44 \%$ of skin cancers and $1.29 \%$ of all specimens), followed by SCC (19.16\% of skin cancers and $0.33 \%$ of all pathologic specimens), and MM (4.91\% of skin cancers and $0.08 \%$ of all pathology specimens). ${ }^{[3]}$ The annual incidence of SCC in the present study was $0.03 \%$. Interestingly, the annual incidence of BCC, SCC, and MF in the present study was similar (Table 3).

The retrospective design and the possibility that not all patients were included due to record-keeping errors are limitations of the present study. Furthermore, precancerous and cancerous lesions may have been missed in some patients who presented with complaints of other cutaneous lesions, and not recorded.

\section{Conclusion}

The present study determined the annual incidence for
2016 of precancerous and cancerous skin lesions among all patients who presented at 3 second level healthcare facility dermatology outpatient clinics. The study included patients from 2 regions of Turkey (Marmara and inner Anatolia) and we think that the findings could be used as a reference for dermatology outpatient clinics in other second level healthcare facilities. However, had the size of the study population been larger and the duration of the study been longer, we could be more certain about our generalizations.

\section{Ethics Committee Approval}

Approval has been obtained from the Bahçeşehir University Ethics Committee (BAU KAEK 2017-04/0I).

Informed Consent

Retrospective medical record evaluation study (none).

Peer-review

Internally peer-reviewed.

Authorship Contributions

Concept: B.A., A.T., E.K.; Design: B.A., A.T., E.K.; Data collection \&/or processing: B.A., A.T., F.T., C.E.; Analysis and/or interpretation: B.A., E.K.; Literature search: B.A.; Writing: B.A.; Critical review: A.T., F.T., C.E., E.K.

Conflict of Interest

None declared.

\section{REFERENCES}

1. Aydemir EH. Paraneoplazik Deri Hastalıkları. Klinik Gelişim 2009;22:14-20.

2. Kim HS, Cho EA, Bae JM, Yu DS, Oh ST, Kang H, et al. Recent trend in the incidence of premalignant and malignant skin lesions in Korea between 1991 and 2006. J Korean Med Sci 2010;25:924-9.

3. Aydın Ö, Polat A, Düşmez D, Eğilmez R. A study of cancer incidence and distribution in Mersin. The Turkish Journal of Pathology 2000;16:48-52.

4. Arıca S, Nazlıcan E, Özer C, Benk Şilfeler D, Arıca V, Özgür T, et al. The frequency and disribution of cancer cases in Hatay District in 2008. Journal of Clinical and Experimental Investigations 2011;2:192-5. [CrossRef]

5. Yalçin B, Tamer E, Toy GG, Oztaş P, Hayran M, Alli N. The prevalence of skin diseases in the elderly: analysis of 4099 geriatric patients. Int J Dermatol 2006;45:672-6. [CrossRef]

6. Çölgecen E, Börekçi E, Kader Ç, Yıldırım T, Özyurt K. Prevalence of Skin Diseases Among Geriatric Patients in The Region of Yozgat. Ankara Üniversitesi Tip Fakültesi Mecmuası 2015;68:119-23.

7. Demirseren DD, Emre S, Ateşkan Ü, Metin A. Prospective analysis of skin findings of patients admitted to a geriatric outpatient clinic. Turkish Journal of Geriatrics 2010;13:87-91.

8. Choi SH, Kim KH, Song KH. Clinical Features of Cutaneous Premalignant Lesions in Busan City and the Eastern Gyeongnam Province, Korea: A Retrospective Review of 1,292 Cases over 19 Years (1995 2013). Ann Dermatol 2016;28:172-8. [CrossRef]

9. Bonerandi JJ, Beauvillain C, Caquant L, Chassagne JF, Chaussade V, 
Clavère $\mathrm{P}$, et al. Guidelines for the diagnosis and treatment of cutaneous squamous cell carcinoma and precursor lesions. J Eur Acad Dermatol Venereol 2011;25 Supp1 5:1-51. [CrossRef]

10. Flohil SC, van der Leest RJ, Dowlatshahi EA, Hofman A, de Vries E, Nijsten T. Prevalence of actinic keratosis and its risk factors in the general population: the Rotterdam Study. J Invest Dermatol 2013;133:1971-8. [CrossRef]

11. Huang YS, Chen XX, Yang SX, Wu LS, Zhao JY, Li XY, et al. Pre- liminary exploration of the clinical features of Chinese patients with skin malignancies and premalignancies: a retrospective study of 1420 cases from Peking University First Hospital. J Eur Acad Dermatol Venereol 2013;27:1114-9. [CrossRef]

12. Sahin N, Bozdag Z, Erk1lic E, Aydin NE, Sener S. Histopathological subtyping of actinic keratosis and it's coexistence with nonmelanotic skin cancers in Gaziantep and Malatya regions. Turkderm - Arch Turk Dermatol Venerology 2016;50:103-8.

\section{Prekanseröz ve Kanseröz Deri Lezyonlarının Sıklığı: Geriye Dönük Çok Merkezli Çalışma}

Amaç: Deri kanserlerinin sıklığı gün geçtikçe artmaktadır. Bu çalışmada amacımız Türkiye'de üç farklı ilde bulunan ikinci basamak özel sağlık kuruluşu dermatoloji polikliniklerine 2016 yılında başvuran ve tanı alarak tedavi edilen kutanöz prekanseröz ve kanseröz lezyon sıklığının tespit edilmesidir.

Gereç ve Yöntem: Çalışmada 2016 yılı boyunca dermatoloji polikliniklerine başvurmuş tüm hastalar geriye dönük olarak değerlendirildi. İlgili ICD kodu taraması ile premalign ve malign kutanöz leyzonları olan hastalara ulaşılarak tıbbi kayıtlarından sosyodemografik ve klinik özellikleri tespit edildi.

Bulgular: Üç farklı dermatoloji polikliniğine başvuran toplam hastaların $(n=21085)$ arasında toplam 8 I olguda prekanseröz ve kanseröz lezyon tespit edildi ve bir yıllık insidansı \% 0.38 olarak saptandı. Tüm başvurular arasında prekanseröz lezyonların $(n=58)$ bir yıl içindeki insidansı $\% 0.27$ ve kanseröz lezyonların ( $\mathrm{n}=23$ ) bir yıl içindeki insidansı \% $0.1 \mathrm{l}$ idi.

Sonuç: Tüm dünyada deri prekanseröz ve kanseröz lezyonlarının sıklığı artmaktadır. Çalışmamızda elde ettiğimiz sonuçlarımız ülkemizde ve dünya çapında daha önce bildirilen bulgular ile uyumluydu. Çalışmamız ülkemizin iki farklı bölgesini (Marmara ve İç Anadolu Bölgesi) içermektedir ve ikinci basamak dermatoloji polikliniği başvuruları göz önüne alındığında referans bir çalışma olabileceğini düşünmekteyiz.

Anahtar Sözcükler: Aktinik keratoz; bazal hücreli karsinom; insidans; kanser; prekanseröz; skuamöz hücreli karsinom. 